\title{
Identification of the Staphylococcus sciuri Species Group with EcoRI Fragments Containing rRNA Sequences and Description of Staphylococcus vitulus sp. nov.
}

\author{
JOHN A. WEBSTER, ${ }^{1 *}$ TAMMY L. BANNERMAN,${ }^{2}$ ROMEO J. HUBNER, ${ }^{1}$ DEBORAH N. BALLARD, ${ }^{2}$ \\ EILEEN M. COLE, ${ }^{1}$ JAMES L. BRUCE, ${ }^{1}$ FRANZ FIEDLER, ${ }^{3}$ KARIN SCHUBERT, ${ }^{3}$ \\ AND WESLEY E. KLOOS ${ }^{2}$

\section{E. I. du Pont de Nemours and Company, Wilmington, Delaware 19880-0402 ${ }^{1}$; North Carolina State University,} \\ Raleigh, North Carolina 27695-76142, and University of Munich, Munich, Germany ${ }^{3}$
}

\begin{abstract}
Strains of a new species, Staphylococcus vitulus, were isolated from food and a variety of mammals. This species was recognized on the basis of the results of an analysis of genomic EcoRI fragments containing portions of the rRNA operons. The patterns of hybridized fragments obtained from strains belonging to the new taxon were sorted into a distinguishable cluster and were distinct from the Staphylococcus lentus and Staphylococcus sciuri patterns. The results of DNA-DNA hybridization reactions demonstrated that strains in this cluster were more closely related to $S$. lentus and $S$. sciuri than to other Staphylococcus species and yet were significantly different. While these strains had some of the phenotypic characteristics of the $S$. sciuri species group, the newly recognized taxon could be distinguished by its very small colonies on $P$ agar, absence of alkaline phosphatase activity, and lack of acid production from L-arabinose, maltose, $N$-acetylglucosamine, D-mannose, and raffinose. The type strain of the new species is strain DD 756 (= ATCC 51145).
\end{abstract}

A general method for distinguishing bacterial species by using restriction fragments containing portions of their rRNA operons has been described previously $(12,26,31)$. This method has been applied to the genus Staphylococcus $(8,9,29)$ and recently was recommended as a way to distinguish a newly described staphylococcus from previously described taxa (7).

In this study, the electrophoretic patterns of restriction fragments labeled by hybridization with an rRNA operon from Escherichia coli were used to characterize organisms belonging to the Staphylococcus sciuri species group. When the patterns were sorted on the basis of similarity by using correlation values, clusters of strains identified as S. sciuri and Staphylococcus lentus were formed. We also distinguished another cluster of novobiocin-resistant, oxidase-positive staphylococci. This third taxon and its relationship to the $S$. sciuri species group are described in this paper.

\section{MATERIALS AND METHODS}

Bacterial strains. In this study, strains were identified by their DuPont numbers. Table 1 shows the strains which we studied, other designations of some strains, the species or subspecies to which each strain belongs, and the source of each strain.

Characteristic determinations. The following characteristics were determined as previously described $(18,19,21,22)$ : colony morphology and pigment, motility, anaerobic growth in thioglycolate broth, catalase activity, acetylmethylcarbinol (acetoin) production, nitrate reduction, tube coagulase activity, clumping factor, hemolysis of bovine blood, carbohydrate reactions, and susceptibility to various antibiotics. Clumping factor and protein A were detected with a Staph Latex kit (Remel, Lenexa, Kans.). The oxidase test was performed by using a Microdase disk (Remel) (10). Pyrrolidonyl arylamidase

\footnotetext{
* Corresponding author. Mailing address: E. I. du Pont de Nemours and Company, Central Research \& Development, E402/4313, Experimental Station, Wilmington, DE 19880-0402. Phone: (302) 695-1613. Fax: (302) 695-8557.
}

activity was determined by using the Pyr broth and Pyr reagent of Carr-Scarborough Microbiologicals (Stone Mountain, Ga.) for identification of group A streptococci and enterococci (13). Esculin hydrolysis was determined on Aesculin agar (CarrScarborough Microbiologicals). Heat-stable nuclease activity was analyzed by using thermonuclease agar supplemented with toluidine blue (Remel) according to the manufacturer's instructions. Ornithine decarboxylase activity was determined by using a modification of the test of Moeller (25), as described in the Manual of Clinical Microbiology (18). Alkaline phosphatase, urease, $\beta$-galactosidase, $\beta$-glucosidase, and $\beta$-glucuronidase activities and arginine utilization were analyzed by using the API STAPH-IDENT system (bio-Merieux Vitek, Hazelwood, Mo.). Additional biochemical profile data were obtained by using the STAPH Trac system (bio-Merieux Vitek)

DNA-DNA hybridization. DNA was isolated and purified by using the procedures of Brenner and coworkers (5), as modified by Kloos and Wolfshohl (23). DNA-DNA hybridization reactions were performed under stringent $\left(70^{\circ} \mathrm{C}\right)$ and optimal $\left(55^{\circ} \mathrm{C}\right)$ conditions, and single- and double-stranded DNAs were separated by using the batch procedure for determining the extent of hybridization and thermal elution of DNA from hydroxyapatite (5).

Patterns: cell and DNA processing. Cells from $3 \mathrm{ml}$ of broth were isolated and lysed in $10 \mathrm{mM}$ Tris- $\mathrm{HCl}-10 \mathrm{mM}$ sodium chloride-50 mM EDTA ( $\mathrm{pH} 8.0$ ) by sequentially adding $30 \mu \mathrm{g}$ of $N$-acetylmuramidase, $600 \mu \mathrm{g}$ of lysozyme, $25 \mathrm{U}$ of lysostaphin, and $10 \mathrm{U}$ of RNase (total volume, $70 \mu \mathrm{l}$ ). Following incubation, $800 \mu \mathrm{g}$ of achromopeptidase in $40 \mu \mathrm{l}$ of water was added. After a second incubation, $126 \mu$ l of a $10 \%$ sodium dodecyl sulfate (SDS) solution and $1.26 \mathrm{mg}$ of proteinase $\mathrm{K}$ (concentration, $10 \mathrm{mg} / \mathrm{ml}$ ) were added. The genomic DNA was isolated by phenol-chloroform-water extraction and ethanol precipitation. The DNA was digested to completion with EcoRI.

Patterns: electrophoresis, transfer, denaturation, and UV cross-linking. The DNA fragments were separated by electrophoresis in a $0.8 \%$ agarose gel in a minigel apparatus. The 
TABLE 1. Staphylococcus strains used, species designations, and sources of strains

\begin{tabular}{|c|c|c|c|c|}
\hline \multicolumn{3}{|c|}{ Strain $^{a}$} & \multirow{2}{*}{$\begin{array}{l}\text { Bacterial species or } \\
\text { subspecies }\end{array}$} & \multirow{2}{*}{ Source } \\
\hline DuPont no. & Kloos no. & Other designation & & \\
\hline DD $756^{\mathrm{T}}$ & & $\operatorname{ATCC} 51145^{\mathrm{T} b}$ & S. vitulus & Ground lamb \\
\hline DD 763 & & ATCC $51162^{b}$ & S. vitulus & Processed chicken \\
\hline DD 768 & & & S. vitulus & Beef, ground chuck \\
\hline DD 771 & & ATCC $51163^{b}$ & S. vitulus & Beef, ground chuck \\
\hline DD 791 & & & S. sciuri & Veal leg, sliced \\
\hline DD $852^{\mathrm{T}}$ & $\mathrm{GH} 137^{\mathrm{T}}$ & ATCC $29974^{\mathrm{T}}$ & S. cohnii subsp. cohnii & Human \\
\hline DD $853^{\mathrm{T}}$ & & ATCC $43958^{\mathrm{T}}$ & S. equorum & Horse \\
\hline DD $854^{\mathrm{T}}$ & & ATCC $35539^{\mathrm{T}}$ & S. gallinarum & Poultry \\
\hline $\mathrm{DD} 857^{\mathrm{T}}$ & $\mathrm{SC} 210^{\mathrm{T}}$ & ATCC $43959^{\mathrm{T}}$ & S. kloosii & Eastern gray squirrel \\
\hline DD $863^{\mathrm{T}}$ & & ATCC $12600^{\mathrm{T}}$ & S. aureus & Human \\
\hline DD $864^{\mathrm{T}}$ & & ATCC $14990^{\mathrm{T}}$ & S. epidermidis & Human \\
\hline DD $866^{\mathrm{T}}$ & & ATCC $15305^{\mathrm{T}}$ & S. saprophyticus & Human \\
\hline DD $869^{\mathrm{T}}$ & $\mathrm{KL} 162^{\mathrm{T}}$ & ATCC $29971^{\mathrm{T}}$ & S. xylosus & Human \\
\hline DD $871^{\top}$ & & $\operatorname{ATCC} 43957^{\mathrm{T}}$ & S. arlettae & Poultry \\
\hline DD 1078 & & CFDRA MDW58 & S. vitulus & Minced beef \\
\hline DD 4201 & OA542 & & S. lentus & Domestic sheep \\
\hline DD 4202 & $\mathrm{~K}-15$ & & S. lentus & Dairy goat \\
\hline DD $4203^{T}$ & $\mathrm{~K}-21^{\mathrm{T}}$ & ATCC $29070^{\mathrm{T}}$ & S. lentus & Dairy goat \\
\hline DD 4204 & $\mathrm{~K}-6$ & & S. lentus & Dairy goat \\
\hline DD $4277^{\mathrm{T}}$ & $\mathrm{SC} 116^{\mathrm{T}}$ & ATCC $29062^{\mathrm{T}}$ & S. sciuri & Eastern gray squirrel \\
\hline DD 4522 & $\mathrm{H} 4 \mathrm{~F} 28$ & & S. vitulus & Yearling horse \\
\hline DD 4523 & V51 & ATCC $51161^{b}$ & S. vitulus & Pine vole \\
\hline DD 4524 & VE 2 & & S. vitulus & Raw veal trimmings \\
\hline DD 4525 & VE 15 & & S. vitulus & Raw veal trimmings \\
\hline DD 4535 & RM112 & & S. sciuri & Black rat \\
\hline DD 4751 & $\mathrm{BH} 2$ & & S. sciuri & Beef head \\
\hline DD 4756 & BT12 & & S. sciuri & Beef trimmings \\
\hline DD 4753 & VE 23 & & S. vitulus & Raw veal trimmings \\
\hline DD 5310 & BC5F4 & & S. lentus & Beef cattle \\
\hline DD 6049 & TT4m1 & & $S$. lentus & Bottlenose dolphin \\
\hline DD 6065 & GMWg12 & & S. vitulus & Pilot whale \\
\hline
\end{tabular}

${ }^{a}$ ATCC, American Type Culture Collection, Rockville, Md.; CFDRA, Campden Food and Drink Research Association, Campden, United Kingdom.

${ }^{b}$ This strain was submitted to the American Type Culture Collection during preparation of the manuscript.

separated DNA fragments were transferred from the agarose gel to a nylon membrane (type NT4HY; Micron Separations, Westborough, Mass.). The DNA was then denatured, and the membrane was dried. The DNA was cross-linked to the nylon membrane by using UV light.

Patterns: probe preparation, bybridization, and detection. A plasmid containing the rRNA operon $(\mathrm{rmB})$ from $E$. coli (6) was linearized with $E c o$ RI and labeled by using a sulfonation reaction (30).

The hybridization cocktail contained $125 \mu \mathrm{g}$ of sonicated and denatured salmon sperm DNA per ml, $0.5 \mathrm{M}$ sodium chloride, and $1 \%$ SDS. For each membrane, $1.5 \mu \mathrm{g}$ of the sulfonated DNA was denatured and combined with $6 \mathrm{ml}$ of hybridization cocktail. After overnight hybridization at $66^{\circ} \mathrm{C}$, the membrane was washed with a $0.5 \mathrm{M}$ sodium chloride- $1 \%$ SDS solution at $66^{\circ} \mathrm{C}$ before it was dried.

The modified DNA probe was detected by using a conjugate consisting of anti-sulfonated DNA monoclonal antibody and alkaline phosphatase $(15,16)$. The monoclonal antibody (Orgenics, Yavne, Israel) was activated with $N$-succinimidyl-4( $N$-maleimidemethyl)cyclohexane - 1 - carboxylate. Sulfhydryl groups were created on the alkaline phosphatase by using $N$-succinimidyl-5-acetylthiacetate and were deprotected with hydroxylamine. Conjugation of monoclonal antibody-maleimide with alkaline phosphatase containing sulfhydryl groups was accomplished by incubating the preparation in the dark. The conjugate was purified on a Zorbax GF-250 column.

After treatment with blocking buffer $(30 \mathrm{~g}$ of skim milk powder [Difco Laboratories, Detroit, Mich.] per $100 \mathrm{ml}$ of 25
$\mathrm{mM} \mathrm{NaCl}-50 \mathrm{mM}$ Tris- $\mathrm{HCl}$ [pH 7.5]-1 mM EDTA-0.3\% Tween 20) and with the conjugate solution, the membrane was washed with assay buffer $(50 \mathrm{mM}$ sodium bicarbonate-carbonate, $1 \mathrm{mM}$ magnesium chloride; $\mathrm{pH} 9.5$ ). After the final wash fluid was decanted, $20 \mathrm{ml}$ of assay buffer and $220 \mu \mathrm{l}$ of chemiluminescent substrate solution PPD $(10 \mathrm{mg} / \mathrm{ml}$; Lumigen, Detroit, Mich.) were added to each membrane preparation. The membrane was removed from the solution, dried, and attached to a plastic frame, and chemiluminescent images were recorded electronically by using a high-sensitivity, supercooled Star One camera (Photometrics, Tucson, Ariz.) in a dark environment. The images were stored on a Macintosh IIci computer (Apple Computer, Cupertino, Calif.).

Patterns: data processing. For each membrane image, the software located the lane positions, reduced the background and noise, scaled each lane's image intensity, and used the data from the lanes containing DNA standards of known sizes to normalize the band positions. The normalized position and intensity profile for each lane, referred to as a pattern, was then stored as an individual record consisting of 512 bytes in a data base.

Additional custom software based on the method of Hubner (14) was used to analyze the levels of correlation between pairs of patterns. This software used the 512 intensity values for each lane as coordinates in a Euclidean, 512-dimensional space. Each pattern represented a single point in the 512-dimensional space. Each pair of patterns was compared by measuring the angle between the pair of lines constructed from the origin of the 512-dimensional space to each of the two points created 
TABLE 2. Results of hybridization of staphylococcal DNAs with $\left[\right.$ methyl $\left.-{ }^{3} \mathrm{H}\right]$ thymidine-labeled DNAs

\begin{tabular}{|c|c|c|c|c|c|c|c|c|c|c|}
\hline \multirow{3}{*}{$\begin{array}{l}\text { Species or } \\
\text { subspecies }\end{array}$} & \multirow{3}{*}{$\begin{array}{l}\text { Pattern } \\
\text { type }^{a}\end{array}$} & \multirow{3}{*}{ Strain } & \multicolumn{8}{|c|}{ \% Relative binding with labeled DNA from: } \\
\hline & & & \multicolumn{2}{|c|}{ DD $756^{T}$} & \multicolumn{2}{|c|}{ DD 771} & \multicolumn{2}{|c|}{ DD 4525} & \multicolumn{2}{|c|}{ DD 4523} \\
\hline & & & $55^{\circ} \mathrm{C}$ & $70^{\circ} \mathrm{C}$ & $55^{\circ} \mathrm{C}$ & $70^{\circ} \mathrm{C}$ & $55^{\circ} \mathrm{C}$ & $70^{\circ} \mathrm{C}$ & $55^{\circ} \mathrm{C}$ & $70^{\circ} \mathrm{C}$ \\
\hline \multirow[t]{8}{*}{ S. vitulus } & dd 756 & DD $756^{\mathrm{T}}$ & 100 & 100 & 81 & 84 & 74 & 81 & 81 & 79 \\
\hline & dd 756 & DD 4753 & 87 & 93 & 97 & 93 & 78 & 84 & 76 & 80 \\
\hline & dd 756 & DD 6065 & 74 & 82 & 81 & 88 & $\mathrm{NT}^{b}$ & NT & NT & NT \\
\hline & dd 771 & DD 771 & 74 & 77 & 100 & 100 & 86 & 81 & 86 & 79 \\
\hline & dd 771 & DD 1078 & 76 & 76 & 84 & 84 & 88 & 84 & 80 & 81 \\
\hline & dd 4522 & DD 4522 & 75 & 75 & 88 & 81 & 88 & 83 & 85 & 84 \\
\hline & dd 4522 & DD 4525 & 74 & 83 & 87 & 83 & 100 & 100 & 84 & 88 \\
\hline & dd 4523 & DD 4523 & 79 & 76 & 85 & 81 & 81 & 82 & 100 & 100 \\
\hline S. sciuri & & DD $4277^{\mathrm{T}}$ & 46 & 10 & 53 & 14 & NT & NT & NT & NT \\
\hline S. lentus & & DD $4203^{T}$ & 38 & 7 & 42 & 15 & NT & NT & NT & NT \\
\hline S. saprophyticus & & DD $866^{\mathrm{T}}$ & 14 & 7 & 25 & 9 & NT & NT & NT & NT \\
\hline S. cohnii subsp. cohnii & & $\mathrm{DD} 852^{\mathrm{T}}$ & 19 & 7 & 28 & 9 & NT & NT & NT & NT \\
\hline S. xylosus & & DD $869^{T}$ & 15 & 5 & 27 & 9 & NT & NT & NT & NT \\
\hline S. kloosii & & DD $857^{\mathrm{T}}$ & 14 & 5 & 29 & 8 & NT & NT & NT & NT \\
\hline S. equorum & & DD $853^{\mathrm{T}}$ & 16 & 6 & 25 & 9 & NT & NT & NT & NT \\
\hline S. arlettae & & DD $871^{\mathrm{T}}$ & 17 & 8 & 28 & 10 & NT & NT & NT & NT \\
\hline S. gallinarum & & DD $854^{\mathrm{T}}$ & 13 & 8 & 14 & 5 & NT & NT & NT & $\mathrm{NT}$ \\
\hline
\end{tabular}

${ }^{a}$ Each pattern type was named after the strain with the lowest DuPont Company number that exhibited that pattern.

${ }^{b}$ NT, not tested.

from the two patterns being compared. Similar patterns had angles approaching zero degrees and cosines approaching unity (one). While the correlation was defined as the cosine of the angle, in this work we routinely used the correlation value squared.

Cell wall analysis. Staphylococci were grown to the stationary phase in a medium containing (per liter of distilled water) $10 \mathrm{~g}$ of tryptone, $5 \mathrm{~g}$ of yeast extract, $5 \mathrm{~g}$ of glucose, and $5 \mathrm{~g}$ of $\mathrm{NaCl}(\mathrm{pH} 7.3)$. The cells were harvested by centrifugation at $20,000 \times g$ for $20 \mathrm{~min}$ at $4^{\circ} \mathrm{C}$ and were disintegrated by shaking the preparation with glass beads. Cell walls were purified with $4 \%$ SDS by using the procedures of Glauner et al. (11) to determine peptidoglycan composition and teichoic acids. For total amino acid analysis cell walls purified with SDS were hydrolyzed with $4 \mathrm{~N} \mathrm{HCl}$ for $16 \mathrm{~h}$ at $100^{\circ} \mathrm{C}$. The levels of amino acids and amino sugars were determined by using a model LC6001 amino acid analyzer (Biotronik, Maintal, Germany). The peptidoglycan type was determined on the basis of the molar ratio of glutamic acid to L-lysine to L-serine to L-alanine to glycine (28). Teichoic acids were extracted from cell walls purified with SDS by the method of Kaya et al. (17). The teichoic acids were purified by ion-exchange chromatography on a column (1.6 by $17 \mathrm{~cm}$ ) filled with DEAE-Sephacel (Pharmacia, Uppsala, Sweden), using a flow rate of $20 \mathrm{ml} / \mathrm{h}$, a base mobile phase consisting of $0.01 \mathrm{M}$ Tris- $\mathrm{HCl}(\mathrm{pH} 7.0)$, and a linear 0 to $1 \mathrm{M} \mathrm{NaCl}$ gradient. The teichoic acids were hydrolyzed with $60 \%$ (wt/vol) hydrofluoric acid for $16 \mathrm{~h}$ at $0^{\circ} \mathrm{C}$ (3). Nonphosphorylated teichoic acid fragments were separated on a column $(1.5$ by $90 \mathrm{~cm})$ filled with Bio-Gel P-2 (Pharmacia) by using a distilled water mobile phase and a flow rate of $8 \mathrm{ml} / \mathrm{h}$. The sugars in the fractions were determined by gas-liquid chromatography, and glycerol was detected enzymatically by the method of Bergmeyer (4). The sugars were completely hydrolyzed with $2 \mathrm{~N} \mathrm{HCl}$ for $3 \mathrm{~h}$ at $100^{\circ} \mathrm{C}$ (3). The hydrolysates were derivatized as described by Albersheim et al. (1) and were subjected to gas-liquid chromatography by using a Packard model GC 438 gas chromatograph equipped with a flame ionization detector (Packard Instrument Co., Meriden, Conn.) and a column ( 2 by $1,000 \mathrm{~mm}$ ) filled with $3 \%$ SP 2340 on 100/200 Supelcoport (Supelco, Bellefonte, Pa.). The gas- liquid chromatography column was equilibrated at $140^{\circ} \mathrm{C}$ and was kept at that temperature for the first $2 \mathrm{~min}$ of each analysis. The temperature was increased at a rate of $6{ }^{\circ} \mathrm{C} / \mathrm{min}$ until it reached $270^{\circ} \mathrm{C}$, where it was kept for an additional 3 min. Phosphate levels were determined by the method of Ames (2).

DNA base composition. The guanine-plus-cytosine content of DNA was determined by A. G. Steigerwalt in the laboratory of D. J. Brenner, Centers for Disease Control, Atlanta, Ga., by using the thermal denaturation method of Marmur and Doty (24).

\section{RESULTS AND DISCUSSION}

DNA-DNA hybridization. The DNA relationships among Staphylococcus vitulus strains that represented different pattern types and between $S$. vitulus and other Staphylococcus species are shown in Table 2.

In DNA-DNA hybridization reactions performed under optimal $\left(55^{\circ} \mathrm{C}\right)$ and stringent $\left(70^{\circ} \mathrm{C}\right)$ conditions, $S$. vitulus strains exhibited relatively high levels of DNA similarity $(82 \%$ $\pm 6 \%$ at $55^{\circ} \mathrm{C}$ and $82 \% \pm 4 \%$ at $70^{\circ} \mathrm{C}$ [means \pm standard deviations]). No significant differences in levels of DNA similarity were found between $S$. vitulus strains that represented different pattern types. However, the levels of DNA relatedness between the new species and other members of the $S$. sciuri species group, including $S$. lentus and $S$. sciuri, were significantly lower. For $S$. lentus, the levels of DNA similarity were $40 \% \pm 2 \%$ at $55^{\circ} \mathrm{C}$ and $11 \% \pm 4 \%$ at $70^{\circ} \mathrm{C}$. For $S$. sciuri, the levels of DNA similarity were $50 \% \pm 4 \%$ at $55^{\circ} \mathrm{C}$ and $12 \%$ $\pm 2 \%$ at $70^{\circ} \mathrm{C}$. The levels of DNA relatedness between $S$. vitulus and other novobiocin-resistant Staphylococcus species that did not belong to the $S$. sciuri species group were even lower.

Patterns. The raw image from a typical agarose gel generated by using enzyme-triggered chemiluminescence and captured with a customized charge-coupled device camera is shown in Fig. 1. The lanes that are not labeled with a species name were used to separate DNA standards whose sizes were known. The positions of the standard bands were used to 


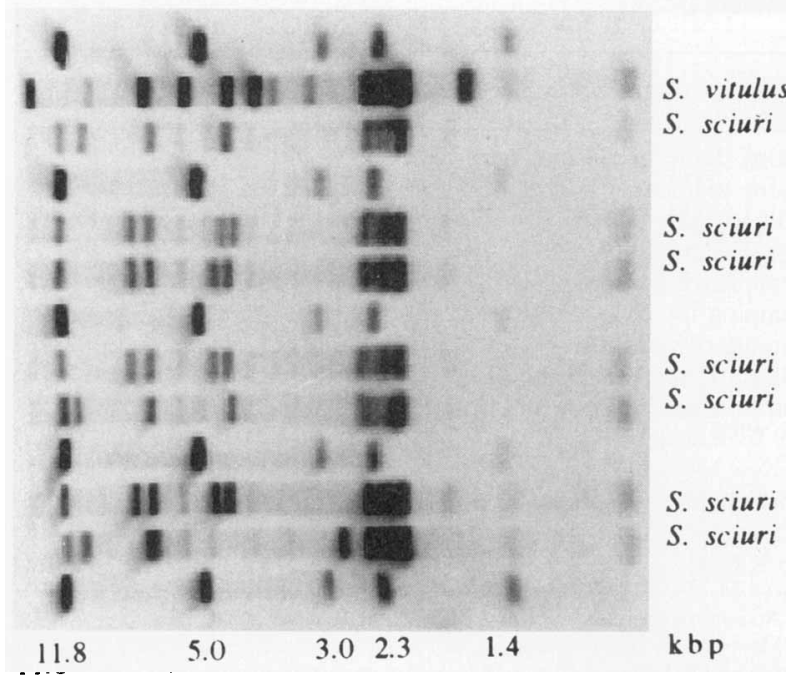

FIG. 1. Electronically recorded image of a membrane containing $E c o$ RI fragments hybridized with a plasmid containing the $r \mathrm{rnB}$ rRNA operon of E. coli.

correct for both lane-to-lane and gel-to-gel variations in band position.

A processed image of some of the patterns determined during this study is shown in Fig. 2. The displayed width of each lane pattern was arbitrarily chosen for Fig. 2. The patterns were arranged to maximize the squared correlation values for adjacent patterns in the display. This sorting revealed that the $S$. vitulus patterns were most similar to the $S$. lentus and $S$. sciuri patterns and were different from the patterns obtained with the more than 200 other species in our data base. $S$. vitulus, $S$. lentus, and $S$. sciuri could be differentiated by their patterns either by visually comparing the patterns or by computer analysis.

Visually, the qualitative differences among the patterns of the three species were obvious. The $S$. vitulus patterns revealed sets of conserved, frequently occurring restriction fragments that were found in different strains of $S$. vitulus but were not conserved as a group in strains of other species.

Patterns that were identical (within the reproducibility of the method) were considered members of the same pattern type. Multiple strains belonging to the same species could have the same pattern type. Each pattern type was named after the lowest-numbered DuPont strain that produced that type of pattern. The $11 \mathrm{~S}$. vitulus strains examined produced four distinguishable types of patterns, dd 756, dd 771, dd 4522, and dd 4523.

Computer analysis provided a way to measure the levels of similarity of the patterns by using the squared correlation values obtained from the 512-dimensional space. All of the $S$. vitulus patterns of the same pattern type (for example, dd 756) had squared correlation values with each other that were greater than 0.85 . When each of the four $S$. vitulus pattern types with was correlated with its nearest $S$. vitulus neighbors in Fig. 2, the squared correlation values ranged from 0.71 to 0.79 . No $S$. vitulus pattern had a squared correlation value with any $S$. lentus pattern that was greater than 0.56 or a squared correlation value with any $S$. sciuri pattern that was greater than 0.46 .

Figures 3 and 4 show two-dimensional representations of the 512-dimensional space. The patterns of more than 5,500 strains, including members of approximately 200 species, were

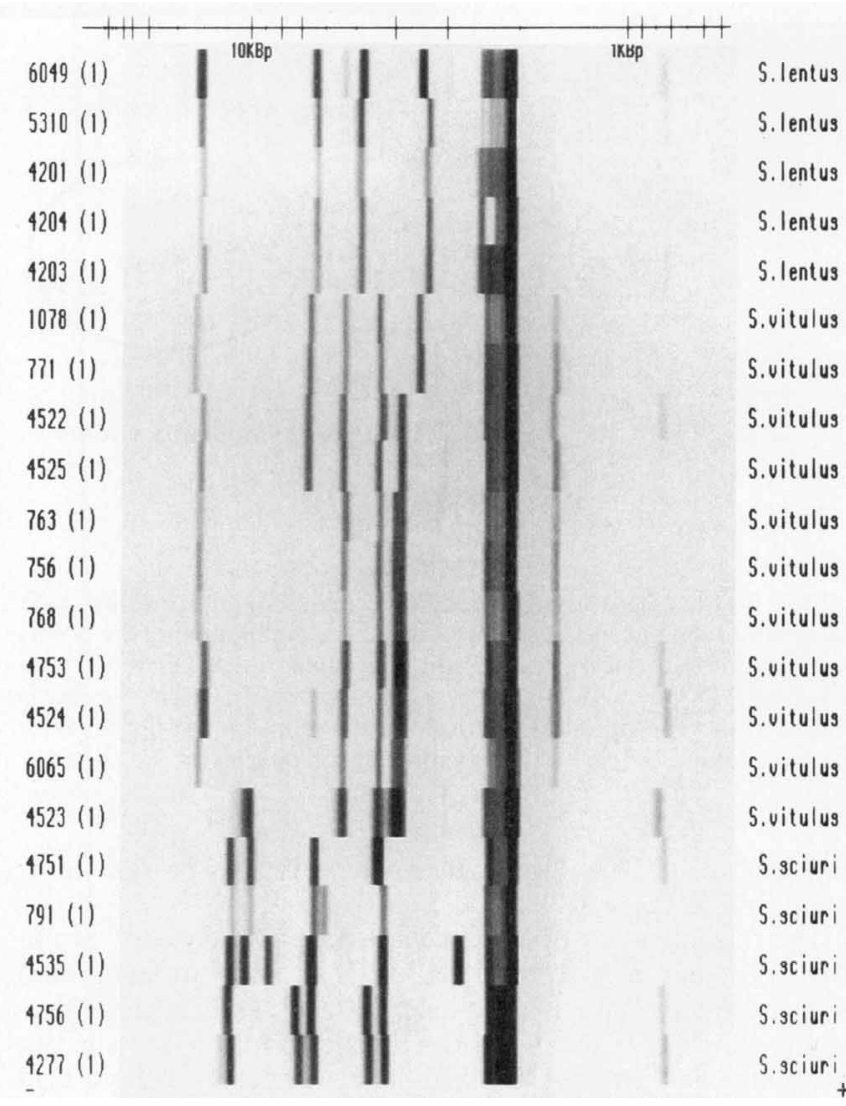

FIG. 2. Patterns of EcoRI fragments containing rRNA sequences derived from image data. The image data for each lane were processed to normalize band positions relative to standards, to reduce background, and to scale the band intensity. The pattern numbers are shown on the left, and the species names are shown on the right.

each defined by a single labeled point in Fig. 3 and 4. In each figure, the squared correlation values with the two reference patterns defined the two dimensions. For Fig. 3 we used the nomenclatural type strain of S. lentus, DD 4203, and the nomenclatural type strain of $S$. vitulus, DD 756, as the reference strains. For Fig. 4 we used the nomenclatural type strain of $S$. vitulus, DD 756, and the nomenclatural type strain of $S$. sciuri, DD 4277 , as the reference strains. In these two-dimensional representations, the visual distinctions between the unique $S$. vitulus cluster and the other species tested are relatively clear. Clusters of points surrounding the reference strains are clearly identified by those reference strains.

Using the complete 512-dimensional-space analysis and the corresponding correlation values, we could clearly distinguish between $S$. vitulus and all of the other species tested. An organism could be identified as a member of $S$. vitulus by the squared correlation value of its pattern obtained from the 512-dimensional-space analysis, even if the pattern did not exactly match one of the pattern types associated with $S$. vitulus. In this study, squared pattern correlation values greater than 0.71 appeared to be strong evidence that strains belonged to the same species.

Cell wall peptidoglycan and teichoic acid. We also determined the peptidoglycan compositions of $S$. vitulus DD $756^{\mathrm{T}}$ (T $=$ type strain), DD 771, and DD 4523, S. lentus DD 4202, $S$. sciuri DD $4277^{\mathrm{T}}$, and Staphylococcus aureus DD $863^{\mathrm{T}}$. The peptidoglycan of $S$. vitulus strains is type L-Lys-L-Ala-Gly ${ }_{3-3.4}$ 


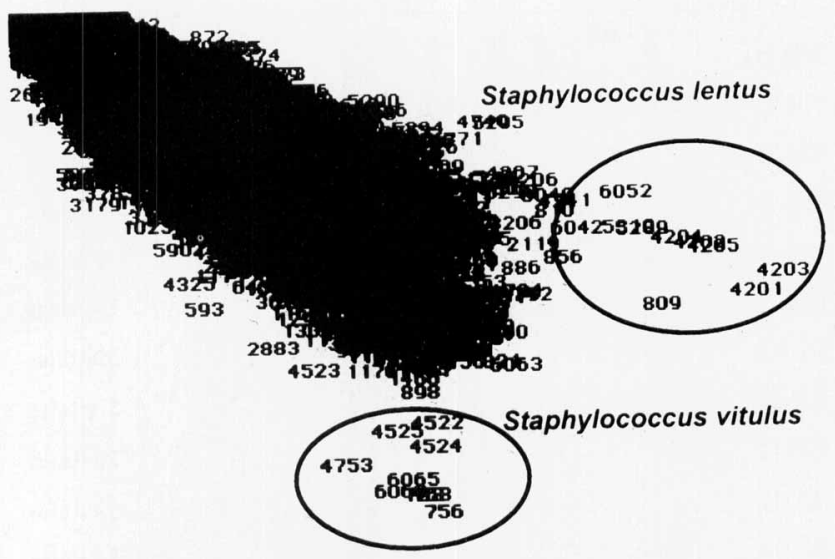

FIG. 3. Clustering of patterns as determined by transforming each pattern into a point in 512-dimensional space and depicting the points in a two-dimensional representation by using $S$. lentus DD $4203^{\mathrm{T}}$ and $S$. vitulus DD $756^{\mathrm{T}}$ to define the two dimensions. The strain number is placed in the appropriate location for each point on the figure. Data for approximately 5,550 strains belonging to 200 species are shown.

peptidoglycan. This peptidoglycan type is also present in $S$. lentus and $S$. sciuri (27).

The teichoic acids of $S$. vitulus are based on glycerol. Strain DD $756^{\mathrm{T}}$ has a glycerol teichoic acid with an integrated $N$-acetylglucosamine 1-phosphate; strain DD 771 has a glycerol teichoic acid substituted at a high level with $N$-acetylgalactosamine; and strain DD 4523 has a glycerol teichoic acid substituted at a low level with $\mathrm{N}$-acetylglucosamine.

DNA base composition. The guanine-plus-cytosine content of $S$. vitulus DD $756^{\mathrm{T}}$ DNA is $34 \mathrm{~mol} \%$; the DNA guanineplus-cytosine content of strains DD 771 and DD 4523 is 35 mol\%; and the $S$. sciuri and $S$. lentus DNA guanine-pluscytosine contents are between 30 and $36 \mathrm{~mol} \%$ (20).

Description of Staphylococcus vitulus sp. nov. Staphylococcus vitulus (vit'u.lus. N. L. n. vitulus, veal). The description of $S$. vitulus below is based on the results of a study of 11 strains.

A total of 10 of the 11 strains produce colonies that are less than $3 \mathrm{~mm}$ in diameter when the organisms are grown aerobi-

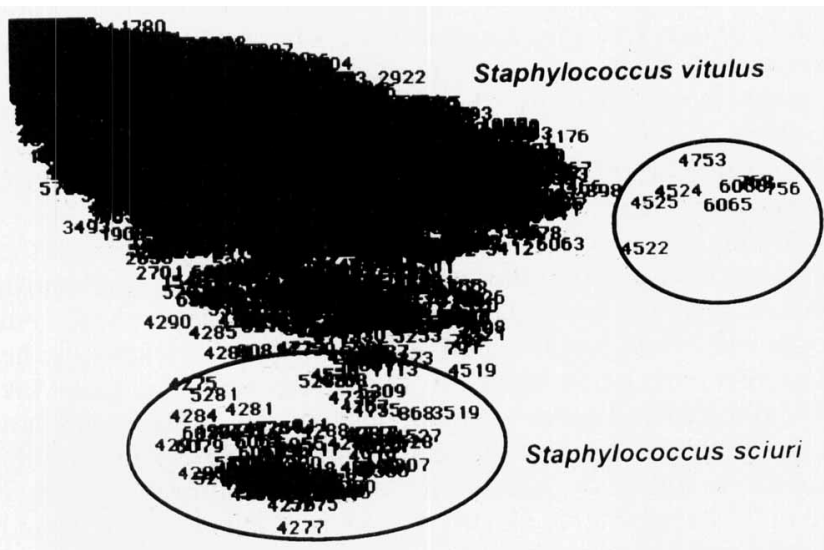

FIG. 4. Clustering of patterns as determined by transforming each pattern into a point in 512-dimensional space and depicting the points in a two-dimensional representation by using $S$. vitulus DD $756^{\mathrm{T}}$ and $S$. sciuri DD $4277^{\mathrm{T}}$ to define the two dimensions. The strain number is placed in the appropriate location for each point on the figure. Data for approximately 5,550 strains belonging to 200 species are shown.
TABLE 3. Variable characteristics of $S$. vitulus strains

\begin{tabular}{|c|c|c|}
\hline Characteristic & $\begin{array}{l}\text { No. of strains positive/ } \\
\text { no. of strains tested }\end{array}$ & $\begin{array}{l}\% \text { of strains } \\
\text { positive }\end{array}$ \\
\hline Colony diam. of $\leq 3 \mathrm{~mm}$ on $\mathrm{P}$ agar & $10 / 11$ & 91 \\
\hline Colony pigment & $10 / 11$ & 91 \\
\hline$\beta$-Glucosidase activity ${ }^{a}$ & $9 / 11^{b}$ & 82 \\
\hline Nitrate reduction & $10 / 11$ & 91 \\
\hline Esculin hydrolysis & $7 / 11(1 / 11)^{c}$ & $64(9)^{c}$ \\
\hline \multicolumn{3}{|l|}{ Clumping factor: } \\
\hline Standard slide test & $0 / 11(2 / 11)$ & $0(18)$ \\
\hline Staph Latex kit (Remel) ${ }^{d}$ & $9 / 11(2 / 11)$ & $82(18)$ \\
\hline \multicolumn{3}{|l|}{ Acid produced aerobically from: } \\
\hline D-Trehalose $\mathrm{e}^{b}$ & $0 / 11(4 / 11)$ & $0(36)$ \\
\hline $\mathrm{D}$-Xylose & $7 / 11(1 / 11)$ & $64(9)$ \\
\hline D-Cellobiose & $2 / 11(1 / 11)$ & $18(9)$ \\
\hline Salicin & $1 / 11(2 / 11)$ & $9(18)$ \\
\hline D-Ribose & $9 / 11(2 / 11)$ & $82(18)$ \\
\hline
\end{tabular}

${ }^{a}$ Activity determined by the API STAPH-IDENT system.

${ }^{b}$ Most strains that produced a dd 756 pattern were positive for $\beta$-glucosidase activity and did not produce acid from mannose or trehalose (the only exception was weak acid production from trehalose by strain DD 6065).

${ }^{c}$ Weak positive reactions were not included as positive reactions. The values in parentheses are the number of strains that exhibited weak positive reactions/ total number of strains tested and the percentage of strains that exhibited a weak positive reaction.

${ }^{d}$ The Staph Latex kit detected both clumping factor and protein A.

cally on $\mathrm{P}$ agar $(18)$ at $35^{\circ} \mathrm{C}$. Colonies on $\mathrm{P}$ agar are usually raised with ulcerated, irregular centers, are opaque, and often have sectored or irregular edges; 10 of the 11 strains studied produce cream to yellow pigmentation, and 1 strain produces unpigmented colonies. Colonies grown on tryptic soy agar are much larger ( 8 to $12 \mathrm{~mm}$ in diameter) and not as irregular as colonies grown on $\mathbf{P}$ agar.

Colony growth is reduced or inhibited at $40^{\circ} \mathrm{C}$, and none of the strains grows at $45^{\circ} \mathrm{C}$. The cells are not motile, and the organisms do not grow anaerobically in thioglycolate semisolid agar. However, they exhibit minimal growth on sheep blood agar and tryptic soy agar plates incubated at $35^{\circ} \mathrm{C}$ in anaerobic jars. The cells are gram-positive cocci, do not form spores, and occur singly, in pairs, in tetrads, and in clusters.

All strains produce zones of greening on bovine blood agar. All strains are negative for staphylocoagulase, thermonuclease, alkaline phosphatase, pyrrolidonyl arylamidase, ornithine decarboxylase, urease, $\beta$-glucuronidase, and $\beta$-galactosidase activities, arginine utilization, and acetoin production. All strains are negative for aerobic production of acid from the following substrates: mannose, lactose, galactose, melezitose, xylitol, rhamnose, turanose, arabinose, maltose, $N$-acetylglucosamine, and raffinose. All strains are negative for anaerobic production of acid from glucose and mannitol. All strains are positive for catalase activity, modified oxidase activity, and aerobic production of acid from the following substrates: mannitol, glycerol, sucrose, and fructose. The variable characteristics of $S$. vitulus are shown in Table 3.

The major API profiles are 4200 (six strains) and 4700 (three strains). STAPH Trac profiles exhibit variation with respect to acid production from maltose, raffinose, xylose, and trehalose, nitrate reduction, alkaline phosphatase, and acetoin production, indicating that there is no predominant profile.

EcoRI fragments containing rRNA sequences. The patterns of all $S$. vitulus strains cluster on the basis of similarity and are distinguishable from the patterns of all other bacteria examined, including all previously described Staphylococcus species. The species can be recognized by a high level of correlation with the pattern types described in this paper. 
TABLE 4. Characteristics that differentiate $S$. vitulus from other novobiocin-resistant, oxidase-positive Staphylococcus species $^{a}$

\begin{tabular}{lccc}
\hline \multicolumn{1}{c}{ Characteristic } & S. vitulus & S. sciuri & S. lentus \\
\hline Colony size of $\geq 6$ mm on P agar & - & + & - \\
Anaerobic growth & - & $(+)$ & $( \pm)$ \\
Staph Latex kit reaction & + & $\mathrm{d}$ & $\mathrm{d}$ \\
$\quad$ Remel) $^{b}$ & & & \\
Hemolysis of bovine blood & $\pm^{c}$ & - & - \\
Alkaline phosphatase activity & - & + & $( \pm)$ \\
B-Glucosidase activity & $\mathrm{d}$ & + & + \\
Esculin hydrolysis & $\mathrm{d}$ & + & + \\
Acid produced aerobically from: & & & \\
D-Trehalose & $(\mathrm{d})$ & + & + \\
D-Mannose & - & $(\mathrm{d})$ & $(+)$ \\
D-Turanose & - & $( \pm)$ & $( \pm)$ \\
D-Xylose & $(\mathrm{d})$ & $(\mathrm{d})$ & $( \pm)$ \\
D-Cellobiose & $(\mathrm{d})$ & + & + \\
L-Arabinose & - & $\mathrm{d}$ & $\mathrm{d}$ \\
Maltose & - & $(\mathrm{d})$ & $\mathrm{d}$ \\
$\quad$-acetyl-D-glucosamine & - & $\mathrm{d}$ & $\mathrm{d}$ \\
Raffinose & - & - & + \\
\hline
\end{tabular}

${ }^{a}+, 90 \%$ or more of the strains are positive;, $\pm 90 \%$ or more of the strains are weakly positive;,- 0 to $10 \%$ of the strains are positive; $d, 11$ to $89 \%$ of the strains are positive. Parentheses indicate that a response is delayed.

${ }^{b}$ The Staph Latex kit detected both clumping factor and protein A.

${ }^{c} S$. vitulus produces greening during this test.

Antibiotic susceptibilities. As determined by agar disk diffusion tests, all strains of $S$. vitulus are susceptible to furazolidone, penicillin, erythromycin, and clindamycin. All strains are resistant to bacitracin and novobiocin. Three strains that produce pattern type dd 756 (DD $756^{\mathbf{T}}$, DD 4524 , and DD 4753) are resistant to tetracycline.

Description of the type strain. The type strain of $S$. vitulus is ATCC 51145 (= DD 756). It has all of the characteristics of the species described above. In addition, it has the properties described below.

Cells are spherical (diameter, 0.9 to $1.1 \mu \mathrm{m}$ ) and occur singly, in pairs, in tetrads, and in clusters.

$\mathbf{P}$ agar colonies are raised with ulcerated, irregular centers, irregular edges, and cream pigmentation; the colonies are approximately $2 \mathrm{~mm}$ in diameter. Colonies on tryptic soy agar are raised with wide, depressed centers; each colony has a slightly irregular edge, and is pigmented, with a pinkish center blending to a cream edge. These colonies are approximately 10 to $11 \mathrm{~mm}$ in diameter. $\beta$-Glucosidase is produced. Nitrates are reduced to nitrites. Esculin is not hydrolyzed. The standard slide test is negative for clumping factor. The Staph Latex kit reaction is strongly positive.

Acid is produced aerobically from D-xylose and D-ribose. No acid is produced aerobically from D-cellobiose, salicin, and D-trehalose.

The type strain is resistant to tetracycline.

The guanine-plus-cytosine content of the DNA is $34 \mathrm{~mol} \%$

The type strain produces a type dd 756 pattern when it is studied by using the methods described in this paper.

Distinguishing characteristics. $S$. vitulus can be distinguished from other bacterial species by examining the pattern of restriction fragments containing rRNA sequences that results when the methods described in this paper are used. $S$. vitulus can also be distinguished by its novobiocin resistance, positive oxidase reaction, strong positive Staph Latex kit reaction, absence of alkaline phosphatase activity, and lack of acid production from $\mathrm{L}$-arabinose, maltose, $\mathrm{N}$-acetylglucosamine, D-mannose, and raffinose. The major phenotypic features that are useful for distinguishing $S$. vitulus from other novobiocin-resistant, oxidase-positive Staphylococcus species are summarized in Table 4.

\section{ACKNOWLEDGMENTS}

We thank Bill Bowen and V. Thayer (National Marine Fisheries, Beaufort, N.C.) for obtaining bacterial specimens from dolphins and a pilot whale and Herman Berkhoff (College of Veterinary Medicine, North Carolina State University, Raleigh) for assisting in obtaining bacterial specimens from dairy cattle and horses. We also thank Joe Neubauer and Channeary Iem (DuPont Company) for technical assistance, Lucy Ganfield and Dipti Schoop (DuPont Company) for preparing the probe and conjugate, and Charles Robertson and Robert Martin for modifying the Star One camera used.

\section{REFERENCES}

1. Albersheim, J. W., D. J. Nevins, P. D. English, and A. Karr. 1967. A method for the analysis of sugars in plant cell wall polysaccharide by gas liquid chromatography. Carbohydr. Res. 5:340-345.

2. Ames, B. N. 1966. Assay of inorganic phosphate, total phosphate and phosphatases. Methods Enzymol. 8:115-118.

3. Anderson, A. J., R. S. Green, and A. R. Archibald. 1977. Specific determination of ribitol teichoic acid in whole bacteria and isolated walls of Bacillus subtilis W23. Carbohydr. Res. 57:C7-C10.

4. Bergmeyer, H. U. 1974. Methoden der enzymatischen Analyse. Verlag Chemie, Weinheim, Germany.

5. Brenner, D. J., G. R. Fanning, A. Rake, and K. E. Johnson. 1969. A batch procedure for thermal elution of DNA from hydroxyapatite. Anal. Biochem. 28:447-459.

6. Brosius, J., A. Ullrich, M. A. Raker, A. Gray, T. J. Dull, R. R. Gutell, and H. F. Noller. 1981. Construction and fine mapping of recombinant plasmids containing the $m B B$ ribosomal RNA operon of $E$. coli. Plasmid 6:112-118.

7. Chesneau, O., A. Morvan, F. Grimont, H. Labischinski, and N. EI Solh. 1993. Staphylococcus pasteuri sp. nov., isolated from human, animal, and food specimens. Int. J. Syst. Bacteriol. 43:237-244.

8. De Buyser, M.-L., A. Morvan, S. Aubert, F. Dilasser, and N. EI Solh. 1992. Evaluation of ribosomal RNA gene probe for the identification of species and subspecies within the genus Staphylococcus. J. Gen. Microbiol. 138:889-899.

9. De Buyser, M.-L., A. Morvan, F. Grimont, and N. El Solh. 1989. Characterization of Staphylococcus species by ribosomal RNA gene restriction patterns. J. Gen. Microbiol. 135:989-999.

10. Faller, A. H., and K. H. Schleifer. 1981. Modified oxidase and benzidine tests for the separation of staphylococci from micrococci. J. Clin. Microbiol, 13:1031-1035.

11. Glauner, B., J. V. Holtje, and U. Schwarz. 1988. The composition of the murein of Escherichia coli. J. Biol. Chem. 263:10088-10095.

12. Grimont, F., and P. A. D. Grimont. 1986. Ribosomal ribonucleic acid gene restriction patterns as potential taxonomic tools. Ann. Inst. Pasteur/Microbiol. (Paris) 137B:165-175.

13. Hébert, G. A., C. G. Crowder, G. A. Hancock, W. R. Jarvis, and C. Thornsberry. 1988. Characteristics of coagulase-negative staphylococci that help differentiate these species and other members of the family Micrococcaceae. J. Clin. Microbiol. 26:1939-1949.

14. Hubner, R. December 1989. U.S. patent 4,885,697.

15. Ishikawa, E., M. Imagawa, S. Hashida, S. Yoshitake, Y. Hmaguchi, and T. Ueno. 1983. Enzyme-labeling of antibodies and their fragments for enzyme immunoassay and immunohistochemical staining. J. Immunoassay 4:209-327.

16. Ishikawa, E., Y. Yamada, S. Yoshitake, and H. Kawaguchi. 1981. A more stable maleimide, $\mathrm{N}$-(4-carboxycyclohexylmethyl) maleimide for enzyme labeling, p. 90-105. In E. Ishikawa, T. Kawai, and K. Miyai (ed.), Enzyme immunoassay. Igaku-Shoin, Tokyo.

17. Kaya, S., Y. Araki, and E. Ito. 1985. Characterization of a novel linkage unit between ribitol teichoic acid and peptidoglycan in Listeria monocytogenes cell walls. Eur. J. Biochem. 146:517-522.

18. Kloos, W. E., and D. W. Lambe, Jr. 1991. Staphylococcus, p. 222-237. In A. Balows, W. J. Hausler, Jr., K. L. Herrmann, H. D. Isenberg, and H. J. Shadomy (ed.), Manual of clinical microbiology, 5th ed. American Society for Microbiology, Washington, D.C. 19. Kloos, W. E., and K. H. Schleifer. 1975. Simplified scheme for 
routine identification of human Staphylococcus species. J. Clin. Microbiol. 1:82-88.

20. Kloos, W. E., and K. H. Schleifer. 1986. Genus IV. Staphylococcus, p. 1013-1035. In P. H. A. Sneath, N. S. Mair, M. E. Sharpe, and J. G. Holt (ed.), Bergey's manual of systematic bacteriology, vol. 2. Williams and Wilkins, Baltimore.

21. Kloos, W. E., K. H. Schleifer, and R. F. Smith. 1976. Characterization of Staphylococcus sciuri sp. nov. and its subspecies. Int. J. Syst. Bacteriol. 26:22-37.

22. Kloos, W. E., T. G. Tornabene, and K. H. Schleifer. 1974. Isolation and characterization of micrococci from human skin, including two new species, Micrococcus lylae and Micrococcus kristinae. Int. J. Syst. Bacteriol. 24:79-101.

23. Kloos, W. E., and J. F. Wolfshohl. 1979. Evidence for deoxyribonucleotide sequence divergence between staphylococci living on human and other primate skin. Curr. Microbiol. 3:167-172.

24. Marmur, J., and P. Doty. 1962. Determination of the base composition of deoxyribonucleic acid from its thermal denaturation temperature. J. Mol. Biol. 4:109-118.

25. Moeller, V. 1955. Simplified tests for some amino acid decarboxylases and for the arginine dihydrolase system. Acta Pathol. Micro- biol. Scand. 36:158-172.

26. Razin, S., M. Gross, M. Wormser, Y. Pollack, and G. Glasser. 1984. Detection of mycoplasmas infecting cell cultures by DNA hybridization. In Vitro (Rockville) 20:404-408.

27. Schleifer, K. H. 1986. Taxonomy of coagulase-negative staphylococci, p. 11-26. In P. A. Mardh and K. H. Schleifer (ed.), Coagulase-negative staphylococci. Almqvist and Wiksell International, Stockholm.

28. Schleifer, K. H., and O. Kandler. 1972. Peptidoglycan types of bacterial cell walls and their taxonomic implications. Bacteriol. Rev. 36:407-477.

29. Thomson-Carter, F. M., P. E. Carter, and T. H. Pennington. 1989. Differentiation of staphylococcal species and strains by ribosomal RNA gene restriction patterns. J. Gen. Microbiol. 135:2093-2097.

30. Verdlov, E. D., G. S. Monastyrakya, L. I. Guskova, T. L. Levitan, V. I. Sheichenko, and E. I. Budowsky. 1974. Modification of cytidine residues with a bisulfite- $O$-methylhydroxylamine mixture. Biochim. Biophys. Acta 340:153-165.

31. Webster, J. A. April 1983. European Patent Office Application 82305061.2 . 